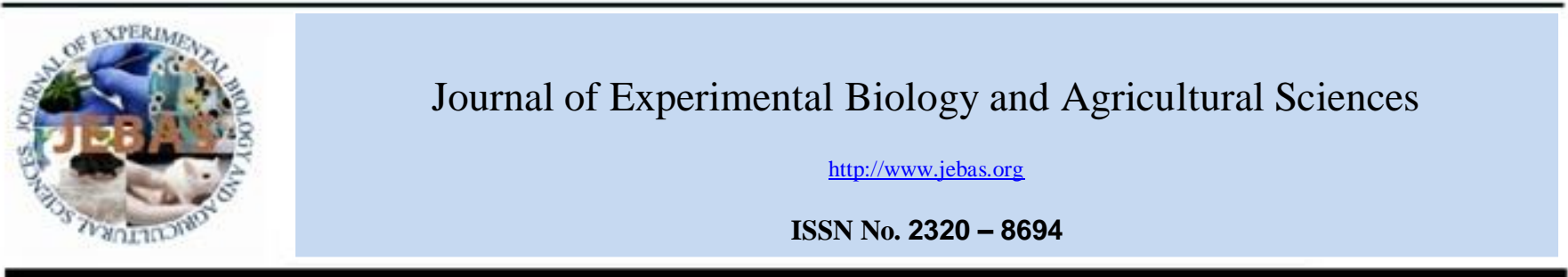

\title{
IMMUNOLOGICAL INTERACTION BETWEEN THE FISH LOUSE Lepeophtheirus salmonis AND THE HOST ATLANTIC SALMON Salmo salar L.
}

\section{Chandravathany Devadason\#}

Department of Cell Biology and Molecular Biology, Marischal College, University of Aberdeen, UK

Received - November 17, 2018; Revision - January 12, 2019; Accepted - January 16, 2019

Available Online - February 5, 2019

DOI: http://dx.doi.org/10.18006/2019.7(1).95.102

\section{KEYWORDS \\ Inflammation \\ Macrophages \\ Migration \\ Parasite \\ Phagocytosis}

\begin{abstract}
The salmon louse, Lepeophtheirus salmonis, is a crustacean ectoparasite of salmonids and causes significant economic losses in Atlantic salmon farms. This study investigated the cellular inflammatory response, specifically macrophage migration, to the attachment of salmon louse to the epidermis of Atlantic salmon (Salmo salar). During the inflammatory response, macrophage infiltration is common at the site of infection in the host macrophages possessing phagocytic activity. The aim of the study was to investigate the immunological response of macrophages to the parasitic excretory and secretory product (E/S). The E/S of the parasites collected from the explants and in vitro cultures of parasites and macrophages isolated from fish blood were used. A macrophage migration and a phagocytosis assay were performed to study the inflammatory response. The inhibition of the macrophage migration response $(p<0.05)$ and a significantly lower level of phagocytosis $(p<0.05)$ were observed. The results indicate that the anti-inflammatory response of the host is elicited during louse infection.
\end{abstract}

* Corresponding author

E-mail: chand_oo@yahoo.com (Chandravathany Devadason)

\# Current Address: Department of Zoology, Eastern University, Sri Lanka, Chenkalady 30350

Peer review under responsibility of Journal of Experimental Biology and Agricultural Sciences.

Production and Hosting by Horizon Publisher India [HPI] (http://www.horizonpublisherindia.in/).

All rights reserved.
All the article published by Journal of Experimental Biology and Agricultural Sciences is licensed under a Creative Commons Attribution-NonCommercial 4.0 International License Based on a work at www.jebas.org.

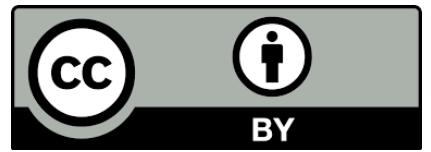




\section{Introduction}

The salmon louse, Lepeophtheirus salmonis, is a crustacean ectoparasite of salmonids and causes significant economic losses in salmon farms (Rae, 1979; Pike, 1989). The Atlantic salmon is more susceptible than other salmon species to Lepeophtheirus infections (Johnson \& Albright, 1992a; Johnson \& Albright, 1992b). Coho salmons treated with corticosteroids are susceptible to infection by sea lice due to a reduced inflammatory response in the fins and gills (Johnson \& Albright, 1992a; Johnson \& Albright, 1992b). Parasites have a complex lifecycle and have different defense strategies to successfully survive in the host via immunosuppressive tactics (Ko, 1989). Cell culture is generally considered to be a useful technique for biochemical (Kusuda et al., 1991) and biotechnological studies related to invertebrate pathology (Maramorosch, 1987), pharmacology, and immunology (Taylor \& Baker, 1978). The development of in vitro cell cultures was established using tissues from shrimp (Luedeman \& Lightner, 1992), lepidopteran, and dipteran insect cultures (Lee \& Hou, 1992), as well as tick cultures (Munderloh et al., 1994). Most in vitro cell culture experiments were performed with the helminth parasite Schistosoma mansoni (Bayne et al., 1994). The host signals for the attachment of various ectoparasites and endoparasites to host explants have been studied in the fish parasite copepodid (Salmincola edwardsii), as well as cercaria of a fish parasite (Acanthostomum japanicum), a duck parasite (Trichobilharzia ocellata), and a human parasite (Schistosoma japonicum). In previous studies, the primary culture of normal pituitary cells of carp (Cyprinus carpio) was found to release gonadotropin during in vitro culture (Ribeiro et al., 1983) and the synthesis of Sarcophaga lectin and sarcotoxins in NIH-SAPE-4 was observed in a Sarcophaga peregrina embryonic cell line (Komano et al., 1988). The adhesion of parasites on to host surfaces has been widely reported in mammalian cell lines (Kirkpatrick \& Svilenov, 1987; Lumb et al., 1988). For endoparasitic protozoans, the attachment of Cryptosporidium sporozoites to Madin-Darby canine kidney (MDCK) cells (Lumb et al., 1988) was demonstrated. Furthermore, it has been reported that Eimeria magna sporozoites attach to embryonic bovine trachea cells (Jensen \& Edger, 1976) and that Eimeriatenella develops in Japanese quail embryos (Nakai et al., 1992). Sarcocystis cruzis porozoites have been found to develop in both bovine monocytes and bovine endothelial cells (Speer \& Dubey, 1986). Primary cell cultures and immortal cell lines grown in a bovine fetal kidney cell culture (Chang \& Gabrielson, 1984) have been established for Toxoplasma gondii (Hughes, 1986). The penetration of Schistosoma mansoni cercaria into a host material, equivalent to living skin, has been previously demonstrated by Fusco et al. (1986). An inflammatory response and extensive cellular infiltration has been observed during parasitic infection (Paperna \& Zwerner, 1982; Johnson \& Albright, 1992a). Hosts rejected the parasitic copepods Lernaea cyprinacea and Lernaea polymorpha (Shariff \& Roberts, 1989). In fish, inflammatory responseshave been observed upon injection of inactivated bacteria (Bartos \& Sommer, 1981), live bacteria (MacArthur \& Fletcher, 1985), extracellular products of Aeromonas salmonicida (Ellis et al., 1976), and parasitic diseases (Cawthorn et al., 1990).

Macrophages and neutrophils secrete a variety of products with defensive functions, such as reactive oxygen species (Secombes et al., 1988), cytokines (Clem et al., 1985), leukotriene B (Knight \& Rowley, 1995), and lipoxins (Rowley, 1991). Several mediators are released at the site of inflammation, namely C5a-like chemotactic complement protein, arachidonic metabolites, such as leukotriene B4 (Samuelsson, 1983), cytokines, interleukin-1 $\beta$, tumor necrosis factor- $\alpha$ (Dinarello, 1991), IL-8 (Ribeiro et al., 1983), macrophage derived chemotactic factor (MNCF) (Cuha \& Ferreira, 1986), bacterial peptides, and LPS (Creamer et al., 1991). Glugea parasitic infection in the three spine stickle back (Weissenberg, 1968) and plaice (McVicar, 1975), and Cryptobiasalm ositica infection in rain bow trout (Jones \& Woo, 1986) have also been previously investigated. The aim of this study was to understand the immunosuppressive effect of $L$. salmonis cultured in vitro, and to determine whether a leucocyte migratory inhibitory factor could be obtained in the supernatant.

\section{Materials and Methods}

\subsection{Experimental Fish}

Atlantic salmon (Salmo salar L.) weighing $1 \mathrm{~kg}$ and $200 \mathrm{~g}$ were obtained from the SOAEFD marine fish farm and maintained in glass fiber tanks with a constant flow (4 1/min) of continuously aerated sea water at $18^{\circ} \mathrm{C}$ and fed an appropriate daily diet of BP commercial pelleted food ( $2 \% \mathrm{w} / \mathrm{w} / \mathrm{day})$. Experimental animals were anaesthetized with benzocaine (Sigma) and euthanized by a sharp blow to the head.

\subsection{In vitro culture of $L$. salmonis}

To allow for copepodid attachment to the in vitro host cell line, the culture medium was optimized by determining the copepodid survival. This was measured as activity and cell viability, determined as the spread of confluent cells and the appearance of cells in different media with varying osmolarity. Mean copepodid survival in percentage was calculated by comparing the number of wells showing copepodid survival to total cells containing copepodids. The mean survival of cells was calculated based on the number of cells showing confluent cell monolayers exposed to copepodid in the wells. The media used were minimum essential medium (MEM) (Gibco), Leibovitz (L-15) (Gibco), sterile water, hosphate buffered saline (PBS), and insect medium (Sigma) at $10^{\circ} \mathrm{C}$. Copepodids were sterilized prior to carrying out the in vitro 
attachment assay. Copepodids were harvested and surface sterilized by washing with sterile culture medium (MEM) three times. Following this, the copepodids were incubated in sterile culture medium (MEM) containing gentamicin (10000 units/ml), penicillin-streptomycin (1000 units/ml), and amphotericin (1000 units $/ \mathrm{ml}$ ) (Sigma, UK)for $3 \mathrm{~h}$ at $18^{\circ} \mathrm{C}$ under aseptic conditions.

A tissue culture plate containing confluent cell monolayers on the collagen matrix was prepared as described above. MEM $(150 \mu 1$, $550 \mathrm{mml} / \mathrm{kg}$ ) was added to each well. The actively sterilized copepodids were then picked up using a pipette. Two copepodids per well were transferred into the culture medium and incubated at $10^{\circ} \mathrm{C}$ in a cooled incubator to enable attachment. Observations were carried out at $12 \mathrm{hrs}$ intervals and the attachment was recorded using a camera. The culture medium was replaced with fresh medium every $48 \mathrm{hrs}$ carefully to avoid disturbing the copepodids or the cell layer.

\subsection{Isolation of leucocytes}

Leucocytes were isolated from the head kidney (HK), for this, pronephros tissue of the $\mathrm{HK}$ was aseptically removed and separated using a $100 \mu \mathrm{m}$ size nylon mesh (Nitex) with $5 \mathrm{ml}$ 1-15 (Gibco) containing 2\% fetal bovine serum (FBS) (Gibco), penicillin/streptomycin (100 units/ml)(Gibco), and 10 units/ml of heparin (Sigma). The cell suspension was placed on a $37-51 \%$ Percoll (Pharmacia) discontinuous density gradient and centrifuged at $400 \mathrm{~g}$ and $4^{\circ} \mathrm{C}$ for 35 minutes. The leucocyte cell fraction was separated from the $37-51 \%$ Percoll interface was resuspended in L-15 (Gibco) containing 1\% FBS (Gibco) and centrifuged at $400 \mathrm{~g}$ for 15 minutes. The cell pellet was collected and resuspended in the same medium and the cell number was adjusted to $1 \times 10^{7}$ cells $/ 100 \mu 1$ with L-15 medium [containing 5\% FBS and penicillin/streptomycin (100 units/ml)] and dispersed into each well of a 96-well tissue culture plate (Nunc). After $3 \mathrm{hrs}$ incubation at $18^{\circ} \mathrm{C}$, non-adherent cells were removed by washing the cell layer with sterile phenol red free HBSS, pH 7.4 (Gibco). The remaining cells were resuspended in L-15 containing $2 \%$ FBS with vigorous pipetting.

\subsection{Production of host chemoattractant containing supernatant}

A chemoattractant containing supernatant was generated from the macrophage monolayer, as described in the section above, by stimulation with a mixture of $50 \mu 1$ of $10 \mu \mathrm{mol}$ calcinophore (Sigma) and $50 \mu \mathrm{l}$ of $50 \mu \mathrm{g} / \mathrm{ml}$ sea lice culture supernatant (SLSN). Likewise, the series of wells containing leucocyte monolayers were also stimulated with control tissue culture supernatant (TCSN) $(80 \mu \mathrm{g} / \mathrm{ml})$, copepodid crude extract (COPE) (50 $\mu \mathrm{g} / \mathrm{ml})$, or Hank's balanced salt solution (HBSS), added together with the above mentioned volumes and concentrations of calcinophore. The plate was incubated for $2 \mathrm{hrs}$ at $18^{\circ} \mathrm{C}$. The leucocyte supernatant was harvested and centrifuged at $1000 \mathrm{~g}$ for $25 \mathrm{~min}$ to remove the leucocytes, then the supernatant was aliquoted and stored at $-20^{\circ} \mathrm{C}$ until further use. Atlantic salmon serum and LPS were also used as the host chemoattractant.

\subsection{Preparation of macrophages treated with parasite products}

The macrophages (HK) of Atlantic salmon were isolated as described previously (section 2.3) and washed twice with sterile HBSS. The cell viability was determined using the $0.1(\mathrm{w} / \mathrm{v})$ trypan blue exclusion method (Phillip, 1973) and the cell number was adjusted to $1 \times 10^{6}$ cells/well $\left(1 \times 10^{7}\right.$ cell $\left./ \mathrm{ml}\right)$ diluted with HBSS. The cells were then incubated with $100 \mu 1$ copepodid culture supernatant (SLSN) and $100 \mu$ lissue culture supernatant $(80 \mu \mathrm{g} / \mathrm{ml})$ or copepodid crude protein extract $(50 \mu \mathrm{g} / \mathrm{ml})$ for $2 \mathrm{~h}$ at $180^{\circ} \mathrm{C}$. Afterwards, the cells were washed thoroughly with sterile HBSS and the viability of cells was observed again as described previously.

\subsection{Leucocyte migration assay}

The migratory responsiveness of freshly isolated Atlantic salmon macrophages (HK) and sea lice culture supernatant-treated macrophages to the abovementioned host chemoattractant was investigated using a technique initially developed by Boydon (1962). A volume of $200 \mu \mathrm{l} /$ well chemoattractant was dispensed into triplicate wells of the 24-well chemotaxis chamber (Nucleopore Corp., Cambridge, MA, USA). The chemoattractants were fresh Atlantic salmon serum (1:4 dilution), calcium ionophore stimulated leucocyte supernatant (1:2 dilution), LPS $(10 \mu \mathrm{g} / \mathrm{ml})$, sea lice culture supernatant (SLSN) $(80 \mu \mathrm{g} / \mathrm{ml})$, copepodid crude protein extracts (COPE) $(50 \mu \mathrm{g} / \mathrm{ml})$, and tissue culture supernatant $(\mathrm{TCSN})(80 \mu \mathrm{g} / \mathrm{ml})$. A $3 \mu \mathrm{m}$ pore size polyvinyl pyrrolidone free polycarbonate filter (Millipore Corp., Bedford, MA, USA) was then placed above the cells. Subsequently, the upper chamber was placed on top of the filter. A volume of $100 \mu \mathrm{l}$ of $2 \times 10^{6}$ cells/well macrophages or macrophages treated with the parasitic supernatants were dispensed into triplicate wells of the upper chamber. The extracted supernatants were added to the lower chamber. The chemotaxis chamber was incubated at $18^{\circ} \mathrm{C}$ for $3 \mathrm{hrs}$. This assay was also carried out with untreated macrophages in the upper chamber as well as the sea lice culture supernatant $(80 \mu \mathrm{g} / \mathrm{ml})$ and the copepodid crude protein extract $(50 \mu \mathrm{g} / \mathrm{ml})$ in the respective lower chambers. After the incubation period, the filter was removed and the upper surface was thoroughly washed with HBSS three times to remove any non-adherent cells on the upper surface. The number of the cells attached to the lower surface of the filter showing directional or chemotactic migratory responsiveness under a microscope $(400 \times$ magnification). The mean of the data was used to calculate the migratory index. 


\subsection{Statistical analysis}

The chemotaxis assay was performed in triplicate on at least six fish. The data were analyzed using analysis of variance (ANOVA). Mini-tab 10 software was used to analyze the raw data.

\section{Results and Discussion}

\section{Macrophages and cell viability}

The number of macrophages collected from the Percoll gradient did not vary significantly between the fish, with a concentration of $1 \times 10^{10}$ cells $/ \mathrm{ml} /$ fish. The contaminating cells were red blood cells and thrombocytes. In these cells, less than 5\% of neutrophils were found. Macrophage viability was determined immediately after isolation, as well as at 2, 6, 12, and $24 \mathrm{hrs}$ using the trypan blue exclusion method. Both immediately after isolation and $2 \mathrm{hrs}$ later, the cell viability was found to be greater than $80 \%$. After 24 hrs, approximately $70 \%$ of the macrophages were viable. After 12 hrs, the cells showed a greatly reduced migratory response compared to that after $6 \mathrm{hrs}$. The cells isolated after $24 \mathrm{hrs}$ did not migrate whereas the cells collected immediately after isolation showed an extensive migratory response after 2 hrs. This observation must be compared with the observations of Atlantic salmon, coho salmon, and chinook salmon experimentally infected with L. salmonis. This demonstrates that Atlantic salmon is more susceptible to L. salmonis infection than coho salmon (Johnson \& Albright 1992a; Johnson \& Albright 1992b). In addition, hydrocortisol-treated coho salmon showed an enhanced susceptibility to L. salmonis infection (Johnson \& Albright 1992a; Johnson \& Albright 1992b). This supports that the copepodid or chalimus might possess an immunosuppressive or antiinflammatory chemotactic factor, apparently inhibiting cell migration (Figure 4). The chemotactic inhibitory factor may be found in soluble form in the secretory product of sea lice, resulting in a significantly lower migratory responsiveness, when macrophages from sea lice culture supernatant were compared to controls (tissue culture supernatant) in the leucocyte migration assay.

\subsection{Treated macrophages and cell viability}

The size of the treated macrophages was enlarged compared to untreated macrophages, with a vacuolated cytoplasm, as seen in Figure 1. Some of the macrophages seemed to have a slightly extended cytoplasmic tail. The cell viability was approximately $60-70 \%$ and lower than that of untreated cells.

\subsection{Leucocyte migration assay}

Viable macrophages were treated with SLSN, TCSN, and copepodid extract in order to confirm the effect on macrophage migration towards the chemoattractant. This assay was performed by comparing treated and untreated macrophages in parallel. Untreated macrophages showed a higher migratory responsiveness compared to treated macrophages in all experiments. Untreated macrophages showed a high migratory responsiveness to fresh Atlantic salmon serum used as a chemoattractant, buta low responsiveness to heat-inactivated Atlantic salmon serum (Table 1). The chemotactic responsiveness of treated cells was significantly lower than that of untreated cells in all experiments when serum was used as a chemoattractant $(p<0.05)$. However, there was no significant difference in the migration of cells treated with sea lice supernatant (SLSN) or tissue culture supernatant (TCSN) $(p>0.01)$.

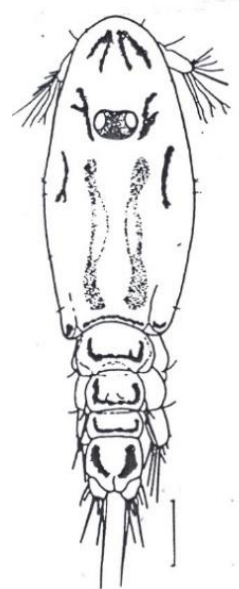

A

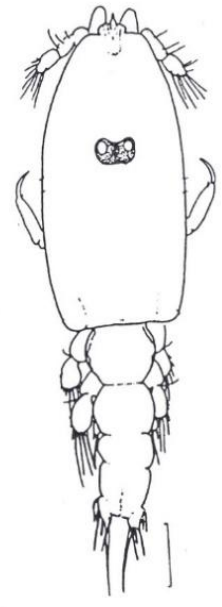

B
Figure 1 Schematic illustration of copepodid (A) Free living stage of copepodid (B) Attached copepodid.

Table 1 Chemotactic activity (number of macrophages (HK) showing migration) when fresh serum was used as the host chemoattractant at different times following isolation.

\begin{tabular}{|cc|}
$\begin{array}{c}\text { Incubation period } \\
\text { (time in hours) }\end{array}$ & $\begin{array}{c}\text { Chemotactic activity (mean number of } \\
\text { cells/ microscopic field) }\end{array}$ \\
\hline 02 & $63 \pm 12$ \\
\hline 06 & $28 \pm 05$ \\
\hline 12 & $12 \pm 03$ \\
\hline 24 & $00 \pm 00$ \\
\hline
\end{tabular}




\section{4 $\mathrm{Ca}^{++}$ionophore stimulated leucocyte supernatant}

The enhanced migratory responsiveness when the $\mathrm{Ca}^{++}$ ionophore-generated leucocyte supernatant was used as a chemoattractant is shown in Figure 2. In this case, macrophages were stimulated with a $\mathrm{Ca}^{++}$ionophore as well as lice products. The supernatants generated were harvested and used as potential chemoattractants. However, they did not show any significant difference in responsiveness compared to the use of $\mathrm{Ca}^{++}$ ionophore alone (Figure 2).

The cells treated with copepodid crude protein extract showed a significantly lower responsiveness when LPS was used $(p<0005)$ (Figure 3$)$. There was no significant difference in migratory responsiveness between treatment and control groups.

Notably, the migratory responsiveness was significantly lower when only sea lice culture supernatant (SLSN) was used as a chemoattractant rather than the control tissue culture product (TCSN) $(p<0.01)$. The macrophages in the presence of the sea lice culture product also showed significantly lower responsiveness compared to cells in the presence of copepodid crude protein product alone (Figure 4).

\subsection{Migratory pattern of macrophages}

After the macrophages migrated through the pores of the filter, the macrophages had a characteristic shape. The cells appeared elongated, with projecting cytoplasmic processes and greater plasticity. In most of the cells, the cellular body containing the nucleus preceded a highly elongated cytoplasmic tail. The migratory pattern of the untreated cells was found to differ from that of the treated cells. Untreated cells showed a highly extended cytoplasmic tail compared to treated cells, indicating that the macrophage receptors are blocked by the crude factors in the culture products.

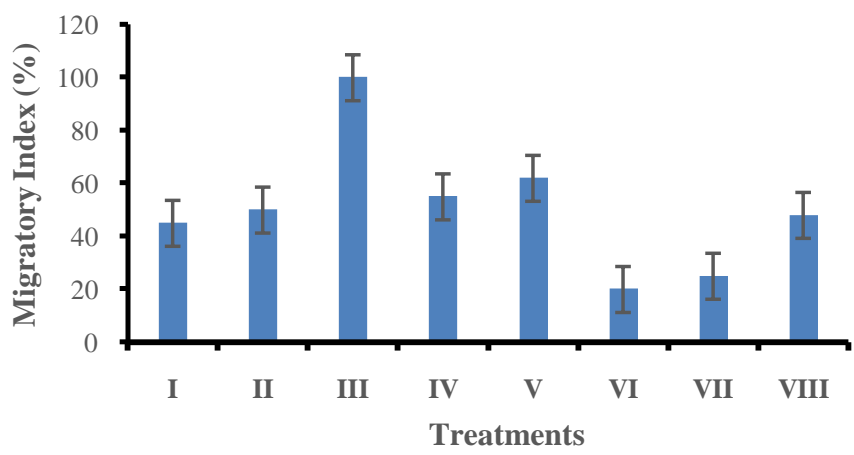

Figure 2 The effect of treatment (SLSN,seal lice culture supernatant) and control (TCSN,tissue culture supernatant) on leucocyte migration to serum attractant represented by the migratory index (\%): I, treated MØ + SLSN/fresh serum; II, treated MØ + TCSN/fresh serum; III, MØ only/fresh serum; IV, treated MØ + SLSN/PBS; V, treated MØ + TCSN/PBS; VI, treated M serum; VII, treated MØ + TCSN/inactivated serum; VIII, MØ only/PBS. $2 \times 10^{6}$ cells $/ 100 \mu 1$ were used. Time of incubation for assay was $3 \mathrm{hrs}$ at $18^{\circ} \mathrm{C}$. Treated MØ were prepared by incubating with the appropriate supernatant for $2 \mathrm{hrs}$. Vertical bars represent the standard error of the migratory index.

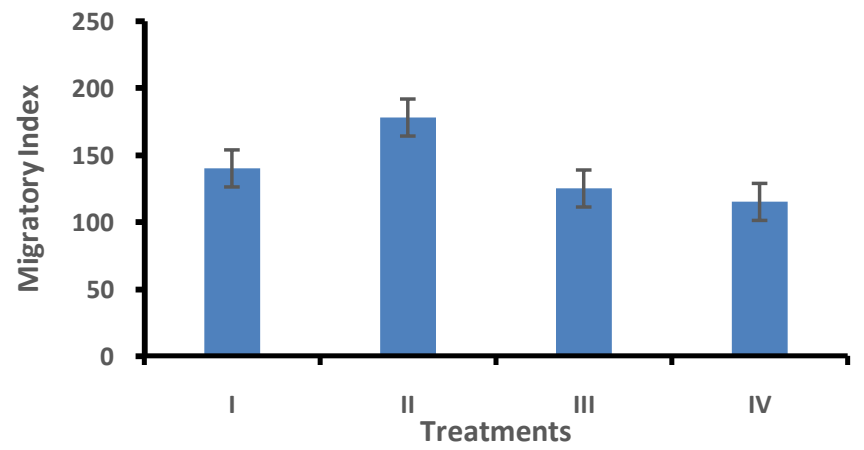

Figure 3 Macrophage migratory responsiveness to various $\mathrm{Ca}^{++}$ionophore stimulated host chemoattractants (CIMS). I, attractant supernatants generated with SLSN $+\mathrm{Ca}^{++}$ionophore; II, TCSN $+\mathrm{Ca}^{++}$ionophore; $\mathrm{III}, \mathrm{HBSS}+\mathrm{Ca}^{++}$ ionophore; IV,copepodid crude extract $+\mathrm{Ca}^{++}$ionophore. $2 \times 10^{6}$ cells $/ 100 \mu 1$ were used. Treated $\mathrm{M} \varnothing$ were prepared by incubating with appropriate supernatant for $2 \mathrm{hrs}$. The incubation time for the assay was $3 \mathrm{~h}$. Vertical bars represent the standard error of the migratory index.

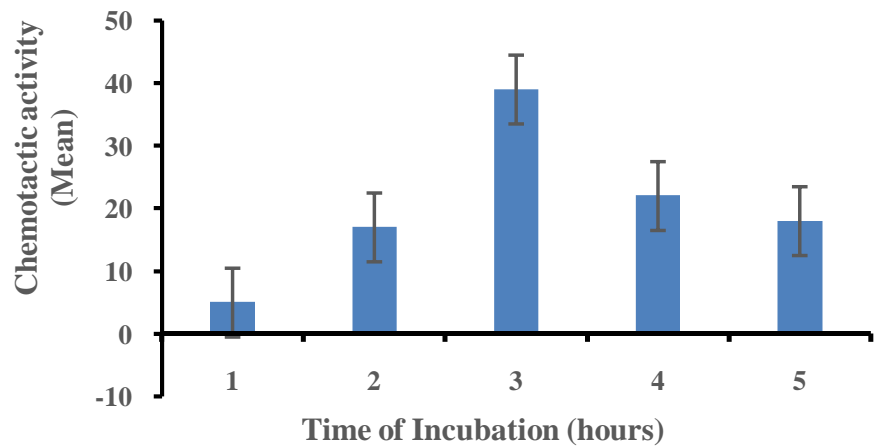

Figure 4 Migratory activity of leucocytes with the time of incubation. Data are represented as the mean \pm standard error (SE). 


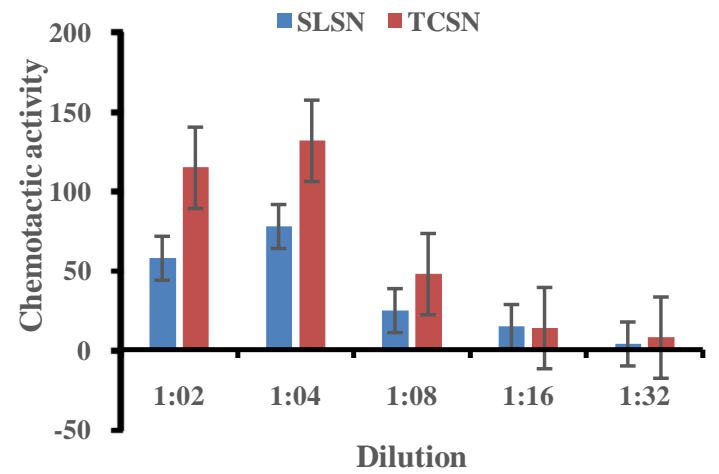

Figure 5 Migratory responsiveness of leucocytes (HK) to the test (blue bar) (SLSN, sea lice culture supernatant) and control (orange bar) (TCSN, tissue culture supernatant). The results represent the mean number of cells $\pm \mathrm{SE}$.

The effect of sea lice secretory/excretory products or crude protein products on the macrophage (HK) migration suggests that the sea lice culture supernatant has chemotactic inhibitory characteristics, as demonstrated by the significantly lower migratory responsiveness towards the sea lice culture supernatant $(p<0.01)$ (Figure 2). Of the different species of salmon experimentally infected with $L$. salmonis, the Atlantic salmon was found to be more susceptible to $L$. salmonis infection than the coho salmon (Johnson \& Albright 1992a; Johnson \& Albright 1992b). Hydrocortisol-implanted coho salmon also showed enhanced susceptibility to L. salmonis (Johnson \& Albright 1992a; Johnson $\&$ Albright 1992b). These findings and the present results suggest that the chalimus secretes an immunosuppressive or antiinflammatory chemotactic factor which seems to inhibit cell migration (Figure 5). In addition, the chemotactic inhibitory factor may be found in a soluble form in the secretory products of sea lice, which caused a significantly lower migratory responsiveness when macrophages were treated with sea lice culture supernatant alone compared to the control (TCSN) in the leucocyte migration assay (Figure 6).

Current study also assessed the migratory responsiveness of untreated and treated macrophages in Atlantic salmon serum, $\mathrm{Ca}^{++}$ ionophore stimulated supernatant, and LPS. An enhanced migratory response to the fresh serum and a significantly lower migratory response to the heated serum were found, suggesting that a chemotactic factor (C5a) in the serum can act as a chemoattractant in this experiment and could be denatured in the heated serum (Figure 4). The C5a-like complement chemotactic factor in the serum enhances vascular permeability and promotes cellular migration, aggregation, and enzyme release of neutrophils, in addition to having the capacity to activate leukocytes and induce leukocyte chemotaxis (Griffin, 1984). The

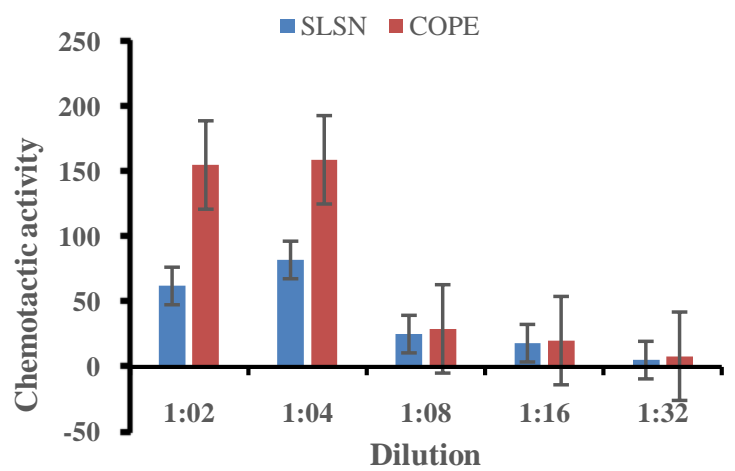

Figure 6 Migratory responsiveness of leucocytes (HK) in the assay. Blue bars represent sea lice supernatant-treated macrophage (SLSN) and orange bars denote copepodid crude extract (COPE). The results represent the mean number of cells \pm SE.

lower migratory response towards LPS exhibited by treated macrophages in response to the copepodid crude product suggests that inhibitory factors may be present in the copepodid (Figure 3).

Figure 5 shows that treated macrophages had a significantly lower migratory response to serum compared to that of untreated macrophages, possibly due to the irreversible blockage of cell receptors or by a direct suppressive affect. When the macrophages were treated with the sea lice supernatant, antigenic agents released into the supernatant were found on the macrophage receptors. In addition, cytokines such as IL-1 or similar compounds may be produced when the macrophages are treated with a sea lice secretory product, as suggested by Smith et al. (1980).

In conclusion, sea lice seem to have an immunosuppressive effect on the host immune system, triggering cell-mediated responses. Further studies also needed to identify the secretory/excretory products released by sea lice in the host as well as to identify the immune suppressive antigen found in the secretory excretory product. The findings presented here provide an insight into the mechanism of infection for the development of commercial antibiotics and vaccines against sea lice infection.

\section{Acknowledgments}

I would like to acknowledge and extend my gratitude to my supervisors, Professors Ian Bricknell, Tony Ellis, and Will Melvin, for their guidance and support, as well as the British Council for their funding.

\section{Conflict of interest}

The corresponding author declares that there is no conflict of interest. 


\section{References}

Bartos JM, Sommer CV (1981) In vitro cell mediated immune response to $M$. tuberculosis and $M$. salmoniphilumin rainbow trout, Salmo gairdneri. Developmental and Comparative Immunology 5: 575-83.

Bayne CH, Meino JS, Hobbs D, Barnes DW (1994)In vitro cultivation of cells from larval Schistosoma mansoni. Journal of Parasitology 80: 29-35. DOI.10.2307/328334.

Boydon S (1962) The chemotactic effect of mixtures of antibody and antigen on polymorphonuclear leucocytes. Journal of Experimental Medicine 115: 453-460.

Cawthorn R, Backman S, Groman D, O'Halloran J, Johnson G (1990) Dermocystidium-like parasite in farmed Atlantic salmon. Canadian Veterinary Journal Review 31: 591.

Chang G, Gabrielson DA (1984) Toxoplasma gondii: growth in ovine fetal kidney cell cultures. Experimental Parasitology 57 : 81-85.

Clem LW, Sizemore RC, Elsaesser CF, Miller NW (1985) Monocytes as accessary cells in fish immune responses. Developmental and Comparative Immunology 9: 803-809.

Creamer HR, Hunter N, Bullock WW, Gabler WL (1991) Concurrent lipopolysaccharide enhances chemotactic response of human polymorphonuclear leucocytes to bacterial chemotaxis. Inflammation 15: 201-211.

Cuha FQ, Ferreira SH (1986) The release of a neutrophil chemotactic factor from peritoneal macrophages by endotoxin inhibition by glucocorticoids. European Journal of Pharmacology 129: 65.

Dinarello CA (1991) The pro-inflammatory cytokines interleukin1 and tumor necrosis factor in septic shock syndrome. Journal of Infectious Diseases 163: 1177-1184.

Ellis AE, Munro ALS, Roberts RJ (1976) Defense mechanisms in fish: A study of the phagocytic system and the fate of intraperitonially injected particulate material in the plaice (Pleuronecte splatessa L). Journal of Fish Biology 8: 67-78.

Fusco AC, Salafsky B, Delbrook K (1986) Schistosoma mansoni, Penetration of cercarial eicosanoids as correlates of penetration and transformation. Journal of Parasitology 79: 444-448.

Griffin BR (1984) Random and directed migration of trout (Salmo gairdneri) leucocytes. Developmental \& Comparative Immunology 7:253-259.

Hughes HPA, Hudson L, Fleck DG (1986) In vitro culture of Toxoplasma gondii in primary and established cell lines. International Journal of Parasitology 16: 317-322.
Jensen JB, Edger SA(1976) Possible secretory function of the rhoptries of Eimeria magna during penetration of cultured cells. Journal of Parasitology 62: 988-992.

Johnson SC, Albright LJ (1992a) Comparative susceptibility and histopathology of the response of naïve Atlantic, Chinook and Coho salmon to experimental infection with Lepeophtherius salmonis (Cpepoda: Caligidae). Diseases of Aquatic Organisms14: 179-193.

Johnson SC, Albright LJ (1992b) Developmental stages of Lepeophtherious salmonis (Kroyer, 1837, Copepod: Caligidae). Canadian Journal of Zoology 69: 929-950.

Jones SRM, Woo PTK (1986) The immune response of rainbow trout, Salmo gairdneri Richardson to the haemoflagellate Cryptobia salmostitica Katz 1951. Journal of Fish Diseases 15:521-527.

Kirkpatrick CJ, Svilenov D (1987) Studies on the adhesion of protoscoleces from Echinococcus multicularis and E. granulosus to artificial substrates and human endothelial cells in vitro. Parasitology Research74: 61-68.

Knight J, Rowley AF (1995)Immunoregulatory activities of eicosanoids in the rainbow trout (Oncorhynchus mykiss). Immunology 85:389 - 393 .

Ko RC (1989)Current Concepts in Parasitology. Hong Kong University Press, Hong Kong.

Komano H, Kasama E, Nakanishi Y, Matsuyama K, Ando K, Nagasawa Y, Natori S (1988) Synthesis of Sarcophaga lectin and sarcotoxins in NIH-SAPE-4, an embryonic cell line of Sarcophaga peregrine. In: Kuroda Y, Kurstak E,Maramorosch K (Eds). Invertebrate and Fish Tissue Culture, Japan Societies Press, Tokyo

Kusuda R, Salati F, Hamaguchi M, Kawai K (1991) The effect of triploidy on phagocytosis, leucocyte migration, antibody and complement levels of ayu, Pleoglossusaltivelis. Fish and Shellfish Immunology 1: 243-249.

Lee H, Hou RF (1992) Establishment of a cell line derived from embryos of the diamond back moth, Plutella xylostella (L). Journal of Invertebrate Pathology 59: 174-177.

Luedeman RA, Lightner DV (1992) Development of an in vitro primary cell culture system from the penaeid shrimp, Penaeus stylirostris and Penaeus vannami. Aquaculture 101: 205-211.

Lumb R, Smith K, O'Donoghue LLA (1988) Ultrastructure of the attachment of Cryptosporium sporozoites to tissue culture cells. Parasitic Research 74: 531-536. 
MacArthur JI, Fletcher TC (1985) Phagocytosis in fish. In: Manning MJ, Tatner MF (Eds.), Fish Immunology, Academic Press, London.

Maramorosch K (1987) Biotechnology in Invertebrate Pathology and Cell Culture. Academic Press, San Diego.

McVicar AH (1975) Infection of plaice Pleuronectes platessa L. with Glugea (Nosema) stephani (Hagenmuller,1899) (Protozoa:Microsporidea ) in a fish farm and under experimental conditions. Journal of Fish Diseases 7:611-619.

Munderloh UG, Liu Y, Wang M, Chen C, Kurtti TJ (1994) Establishment, maintenance and description of cell lines from the tick, Ixodes scapularis. Journal of Parasitology 80: 533-543.

Nakai Y, Tsuchiya H, Takahashi S (1992) Cultivation of Eimeria tenella in Japanese quail embryo. Journal of Parasitology78: 1024-1026.

Paperna L, Zwerner DE (1982) Host-parasite relationship of Ergasilus labracis Kroyer (Cyclopidea, Ergasilidae) and the striped bass, Morone saxatilis (Walbaum) from the lower Chesapeake Bay. Annales De Parasitologie Humaine Et Comparee 57: 393-405

Phillips HJ (1973) Dye exclusion tests for cell viability. In: Kruse PK, Patterson MK (Eds.), Tissue Culture Methods and Application, Academic Press, New York.

Pike AW (1989) Sea lice - Major pathogens of farmed Atlantic salmon. Parasitology Today 5: 291-297.

Rae GH (1979) On the trail of the sea louse. Fish Famer 2: 22-25.
Ribeiro LP, Ahne W, Lichtenberg V (1983) Primary culture of normal pituitary cells of carp (Cyprinus carpio) for the study of gonadotropin release. In Vitro19: 41-45. DOI. 10.1007/BF0261799.

Rowley AF (1991) Lipoxin formation in fish leucocytes. Biochimica et Biophysica Acta1084: 303-306.

Samuelsson B (1983) Leukotrienes: mediators of immediate hypersensitivity reactions and inflammation. Science 229: 568 .

Secombes CJ, Chung S, Jeffries AH (1988) Superoxide anion production by rainbow trout macrophages detected by the reduction of ferricytochrome. Developmental Comparative Immunology 12: 201-206.

Shariff M, Roberts R (1989) The experimental histopathology of Lernaeapolymorpha $\mathrm{Yu}, 1983$ infection in naïve Aristichthysnobilis (Richardson) and a comparison with the lesion on naturally infected clinically resistant fish. Journal of Fish Diseases 12: 405-414.

Smith KA, Lachman LB, Oppenheim JJ, Favata MF (1980) The functional relationship of the interleukins. Journal of Experimental Medicine151: 1551.

Speer CA, Dubey JP (1986) Vascular phase of Sarcocystis cruzi cultured in vitro. Canadian Journal of Zoology 64: 209-211.

Taylor AER, Baker JR (1978) Methods of Cultivating Parasites in vitro. Academic Press, London.

Weissenberg R (1968) Intracellular development of the microsporidian Glugeaanomala in hypertrophying migratory cells of fish Gasterosteus aculeatus: an example of the formation of xenoma tumors. Journal of Protozoology 15: 44-57. 